\title{
Ovule-bearing reproductive organs of the glossopterid seed ferns from the Late Permian of the Beardmore Glacier region, Antarctica
}

\author{
E. L. Taylor, ${ }^{1,2}$ T. N. Taylor, ${ }^{1,2}$ and P. E. Ryberg ${ }^{1}$ \\ ${ }^{1}$ Department of Ecology and Evolutionary Biology, University of Kansas, 1200 Sunnyside Avenue, Lawrence, KS 66045-7534, USA \\ (etaylor@ku.edu, tntaylor@ku.edu, rybergp@ku.edu) \\ ${ }^{2}$ Natural History Museum and Biodiversity Research Center, University of Kansas, 1200 Sunnyside Avenue, Lawrence, KS 66045-7534, USA
}

\begin{abstract}
The Glossopteridales are an extinct group of seed ferns that dominated Gondwana during the Permian. The strap-shaped leaves of Glossopteris are widespread and provided early evidence of continental drift, but reproductive organs of this group have remained enigmatic since they were first described in the 1950s. Based on compressionimpression fossils, there are at least two basic types of ovulate (seed-bearing) organs. In one form, numerous ovules are borne on the surface of a leaf-like megasporophyll (e.g., Plumsteadia, Dictyopteridium), while the second type consists of stalked, apparently uniovulate cupules borne on a branching system (e.g., Lidgettonia). More than 30 genera of seedbearing organs have been described, many based on compressions or, more commonly, impression fossils, in which it is often impossible to discern the three-dimensional morphology or attachment of these structures. Both morphological types have now been found in permineralized peat from Skaar Ridge, central Transantarctic Mountains (CTM), and provide some of the first anatomical detail of the diversity of reproductive organs of Glossopteris. The multiovulate organ is small (6 mm wide), with ovules borne on the upper (adaxial) surface; the uniovulate structure consists of four stalked cupules, each containing a single ovule about $2 \mathrm{~mm}$ long. These two forms provide important information about the diversity of the glossopterids and their status as a natural group of seed plants.

Citation: Taylor, E.L., T.N. Taylor, and P.E. Ryberg (2007), Ovule-bearing organs of the glossopterid seed ferns from the Late Permian of the Beardmore Glacier region, Antarctica, in Antarctica: A Keystone in a Changing World - Online Proceedings of the $10^{\text {th }}$ ISAES, edited by A.K. Cooper and C.R. Raymond et al., USGS Open-File Report 2007-1047, Short Research Paper 082, 4 p.; doi:10.3133/of2007-1047.srp082
\end{abstract}

\section{Introduction}

The glossopterid seed ferns (pteridosperms) have occupied both a prominent and perplexing position in the history of paleobotany, prominent because the spathulate Glossopteris leaves with complex venation represented some of the earliest evidence for the existence of the supercontinent Gondwana and subsequent movement of continental plates, and perplexing because the phylogenetic position of the group has continued to remain equivocal. While Glossopteris has been used as an index fossil for the Permian, it has also been described from the Early Triassic of India (Pant and Pant, 1987; Shah, 2000) and from the Fremouw Formation in Antarctica (McManus et al., 2002), which has previously been considered to be Triassic (Collinson et al., 2006). McLoughlin (1993) noted that while some glossopterid reproductive organs may be used in biostratigraphy, leaves and other vegetative organs are not useful for correlation due to problems in delimiting species, especially among impression floras. Permineralized leaves have been described from Antarctica (Pigg, 1990) and Australia (Gould and Delevoryas, 1977; Pigg and McLoughlin, 1997), along with evidence of their attachment to the parent plant (Pigg and Taylor, 1993). The distinctive roots of the Glossopteris plant, Vertebraria (e.g., Neish et al., 1993), can be identified in both compression-impression and permineralized specimens. Glossopteris remains have been found in a number of types of depositional environments in Antarctica (Cúneo et al., 1993).

The ovule-bearing structures of the glossopterids continue to be poorly understood; many are known only from impression fossils, making interpretation of threedimensional morphology difficult. Numerous taxa have been erected based on size, shape, number of ovules (often only ovule scars), and various other features (see, e.g., Surange and Chandra, 1975; Pant, 1977; Rigby, 1978; McLoughlin, 1990a, 1990b). Attachment of reproductive organs to the parent plant is based on impression specimens only and is controversial.

All glossopterid ovulate reproductive organs suggest a basic morphological organization in which a vegetative leaf subtends a structure that bears ovules or seeds. Historically, this seed-bearing unit has been termed a megasporophyll, cupule, or other, less specific morphological entities (e.g., fertiliger, capitulum, cladode); the latter terms are no longer in use. The reproductive structure is generally regarded as an axillary shoot that has become reduced and flattened evolutionarily (e.g., Doyle, 2006), much like the secondary shoot of the cordaites (Schopf, 1976). In some cases, this structure appears to be adnate to a typical Glossopteris leaf, although this is difficult to confirm based only on impressions. Gould and Delevoryas (1977) provided the first description of a structurally preserved, seed-bearing organ from the Bowen Basin, Australia. It showed definitively that the ovules were borne on a leaflike megasporophyll, thus confirming the assignment of these plants to the pteridosperms. Another permineralized megasporophyll (Figs. 1,2) was described from the Permian of Antarctica (Taylor and Taylor, 1992); it provided additional evidence that the ovulate organ was a megasporophyll, and showed that the seeds were borne on the adaxial (upper) surface of the megasporophyll (Fig. 2), based on the orientation of the vascular bundles. The presence of bisaccate, striate pollen 
grains in the pollen chambers (Fig. 3) confirmed the glossopterid affinities. Nishida et al. (2007) have recently confirmed that the ovules in the Bowen Basin specimens were borne on the anatomically adaxial surface of the megasporophyll. The exact relationship between the megasporophyll and the subtending leaf, however, has yet to be determined, and is an important piece of the puzzle that is needed to accurately homologize the ovule-bearing structures with other seed plants.

An examination of the more than 30 ovulate organ morphogenera that have been named to date suggests that there are two basic types, as previously suggested by Surange and Chandra (1975). The multiovulate type consists of a flattened, leaf-like megasporophyll, e.g., Plumsteadia (Rigby, 1962; McLoughlin, 1990a) and the cupulate type consists of a branching structure, e.g., Denkania (Surange and Chandra, 1973) or Lidgettonia (Thomas, 1958). Both structures are subtended by a vegetative leaf and presumed to represent ovulate organs, although ovules are often not preserved. The multiovulate types often show only scars where the ovules would be attached (e.g., McLoughlin, 1990b). In impression fossils with no cuticle preserved (e.g., Anderson and Anderson, 1985), it is often difficult to determine whether structures represent ovules or ovule scars. The preliminary description of an ovule-bearing structure in this paper represents the first to provide anatomical details of the cupulate type of reproductive organ.

\section{Material and methods}

The specimen (\#13677) is from a silicified peat in the Upper Buckley Formation, Skaar Ridge, Beardmore Glacier region, CTM $\left(84^{\circ} 49^{\prime} 15.8^{\prime \prime} \mathrm{S}, 163^{\circ} 20^{\prime} 18.9^{\prime \prime} \mathrm{E}\right.$, Buckley Island Quadrangle, Barrett and Elliot, 1973; Taylor et al., 1989) and is considered Late Permian, based on floral content and palynology (Farabee et al., 1991). Acetate peels were made of the surface after etching in hydrofluoric acid (Galtier and Phillips, 1999); peels were mounted on slides for light microscopy and digital photography. All materials are housed in the KU Natural History Museum, Division of Paleobotany (http://paleobotany.bio.ku.edu/PaleoCollections.htm).

\section{Results}

The new cupulate organ consists of four small, uniovulate cupules that appear to be arranged in a C-shaped pattern. Each cupule is approximately $3 \mathrm{~mm}$ long and 1 $\mathrm{mm}$ in diameter (Figs. 4, 5) and contains a single ovule; the cupule extends distally beyond the level of the micropyle. Ovules are sessile, orthotropous, and approximately $2 \mathrm{~mm}$ long. The multilayered integument has short wings at the apex, and bilaterally symmetrical ovules (1.2-2.0 $\mathrm{mm}$ wide in the primary plane). These features distinguish this ovule from the similar-sized, obovoid ovules of Chaonostoma (Klavins et al., 2001) previously described from this same locality. The cupules are attached to the distal end of an axial system; each axis undergoes two dichotomies resulting in a total of four uniovulate cupules in each unit (Fig. 5). One dichotomy, resulting in two terminal cupules, is shown in Figure 5. The most proximal end of the cupule axis has a C-shaped vascular strand. This cupulate structure, like the megasporophyll previously described from Skaar Ridge, is not preserved attached to the parent plant or in relationship to a vegetative leaf, and thus the homologies of the fertile organ continue to remain imprecise.

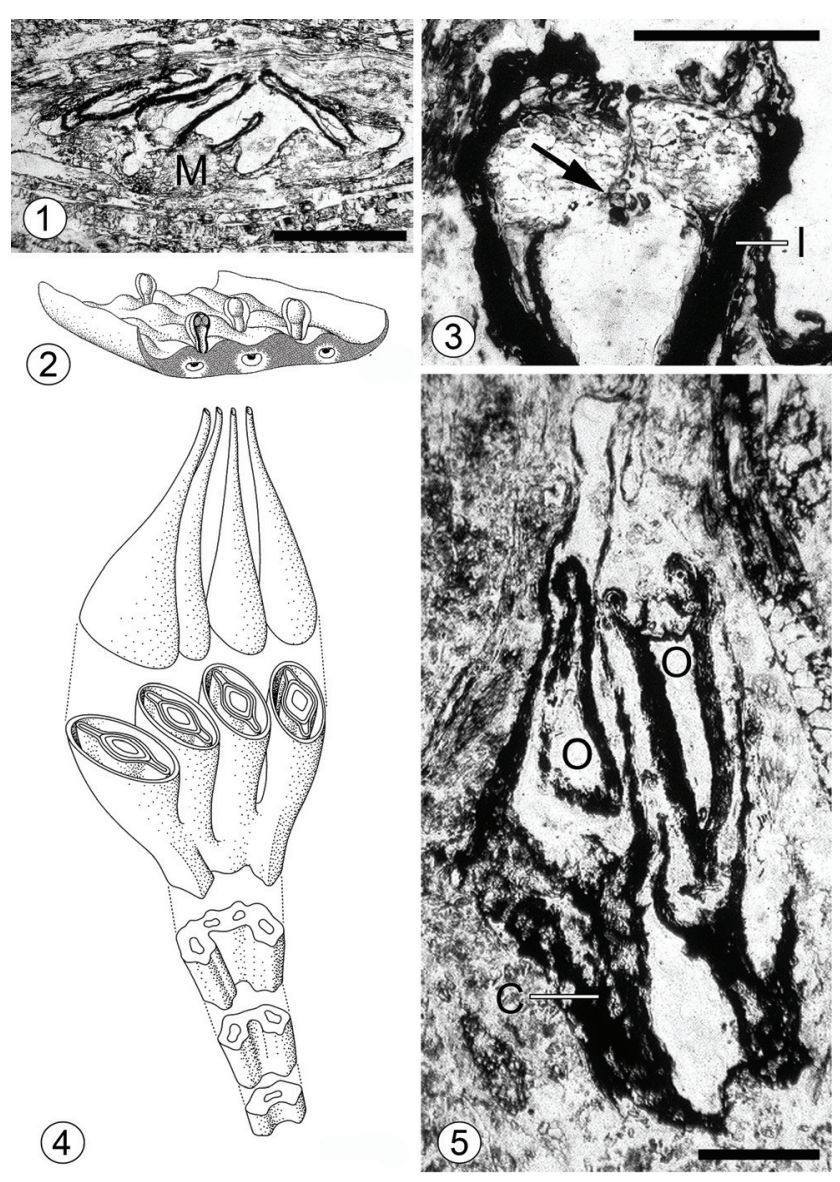

Figure 1. Cross section of multiovulate megasporophyll (M) with several ovules attached to adaxial surface. One ovule (just left of M) has broken off and is reversed, with its micropyle pointing back towards the megasporophyll. Two ovules (above M and, right) are still attached (see Taylor and Taylor, 1992 for further explanation); Scale bar $=2 \mathrm{~mm}$. Figure 2. Suggested reconstruction of megasporophyll in Figure 1 (redrawn from Taylor and Taylor, 1992). Figure 3. Longitudinal section through the micropylar end of a dispersed ovule of the same type as Fig. 1, showing pollen grain (arrow) and poorly preserved integument (I); Scale bar $=1 \mathrm{~mm}$. Figure 4. Suggested reconstruction of cupulate organ in Fig. 5. Figure 5. Section of cupulate reproductive organ with two terminal branches, each with a single, uniovulate cupule (one on left marked $\mathrm{C}$ ). $\mathrm{O}=$ ovule. The cupule on the left extends above the seed (see two thin lines above). Note connection of two cupules at the base (= point of dichotomy). Scale bar $=1 \mathrm{~mm}$. 


\section{Discussion}

The permineralized specimens from Antarctica confirm the existence of two morphological types of ovulebearing reproductive organs in the glossopterid seed ferns, an idea which was initially proposed based on compression-impression remains only (see, e.g., Surange and Chandra, 1975). They also provide the first definitive evidence of ovules borne within cupules, since the impression taxa described to date have no cellular details preserved. One type consists of a flattened leaf bearing a few to many seeds on the adaxial surface, the multiovulate type (e.g., Gould and Delevoryas, 1977; Taylor and Taylor, 1992; Nishida et al., 2007), and the second type encompasses uniovulate cupules borne terminally on elongate stalks, which themselves are part of a branching system (cupulate type). Both morphotypes contain orthotropous ovules and integumentary structures vary among taxa.

Compression-impression material suggests that both types of ovulate structures were borne in some relation to a vegetative leaf, either along the petiole on the upper (adaxial) surface of the leaf or in an axillary position. Only a very few specimens have been described that show glossopterid ovulate organs compressed laterally, so that the relation of the megasporophyll and the subtending vegetative leaf can be seen clearly. One of these, described by Pant and Singh (1974), shows a stalk terminated by an enlarged, flattened megasporophyll bearing numerous ovules on the surface. The stalk is attached in the axil of a typical vegetative leaf of $G$. taenioides with the ovules facing the stem (i.e., apparently on the adaxial surface of the megasporophyll). Based on this and other observations, Pant hypothesized in several publications (e.g., Pant and Singh, 1974; Pant, 1977) that all the multiovulate types bore their ovules on the adaxial (upper) surface of the megasporophyll, which was then attached to the stem in the axil of a vegetative leaf. Holmes (1973) also illustrated a specimen of Austroglossa walkomii with an attached axillary stalk bearing a megasporophyll and ovules. The specimen is somewhat crushed and may be twisted, but he hypothesized, based on this fossil, that the ovules were borne on the abaxial (lower) surface of the megasporophyll. In this scenario, the ovules would face the vegetative leaf and be appressed to it. Anatomical studies have now clearly demonstrated (Taylor and Taylor, 1992; Nishida et al., 2007) that the ovules were attached to the adaxial (upper) surface of the megasporophyll, based on the orientation of the vascular bundles in the structure.

Several authors have reconstructed the glossopterid megasporophyll with the ovules attached to the abaxial (lower) surface of the megasporophyll (e.g., Schopf, 1976; Retallack and Dilcher, 1981) and these reconstructions have been widely copied. These interpretations, however, have relied heavily on theoretical considerations necessary to evolve the angiosperm carpel from the glossopterid megasporophyll (e.g., Doyle, 2006). Information from compressed fossils does suggest that the ovules probably faced the surface of the subtending Glossopteris leaf (e.g., McLoughlin, 1990a), that is, they faced abaxially, but the permineralized structures from Antarctica and Australia illustrate that anatomically, the ovules were borne on the adaxial surface of the megasporophyll. This result would imply that either the peduncle of the megasporophyll was twisted at the base, or perhaps the vascular bundles twisted, either in the stem or in the peduncle, a situation known to occur in cycad leaves (Le Goc, 1914; Hermsen et al., 2007).

\section{Glossopterid reconstructions and phylogenetic relationships}

In attempting to elucidate the phylogenetic position of the Glossopteridales, many authors have considered the group as a single terminal clade in phylogenetic analyses (e.g., Nixon et al., 1994; Doyle, 2006; Hilton and Bateman, 2006). To date, there is no whole-plant reconstruction of a Glossopteris plant based on organic attachment or anatomical evidence, so the 'Glossopteris' plant used in phylogenetic analyses has been a composite of morphotaxa based on dispersed organs, which masks the potential diversity in the group. A number of impressioncompression leaf specimens have been described attached to axes (see references in Pigg and Taylor, 1993). Taylor and Taylor (1992) attributed the small megasporophyll from Antarctica to the same plant that bore G. schopfii (Pigg, 1990) leaves, based on similar anatomy of the vascular bundles. Pigg and Taylor (1993) described leaves of G. skaarensis, also from the Antarctic permineralized peat, attached to woody stems assigned to the morphotaxon Araucarioxylon. Pigg and Nishida (2006) reconstructed three 'whole plants' of Glossopteris based on permineralized specimens, one with $G$. homevalensis leaves from Australia, and two based on G. schopfii and G. skaarensis leaves from Antarctica; these leaf species also occur in Australia. Immature ovulate organs have been found attached to axes with $G$. homevalensis leaves, but these cannot be related to the mature ovulate structure from the Homevale locality (Pigg and Nishida, 2006; Nishida et al., 2007). With the exception of the ovulate organ of Taylor and Taylor (1992) and the immature structure, all reconstructions to date consist of vegetative parts only. Any attribution of reproductive organs has been based on common occurrence at the same locality, and pollen organs have not been described from these sites. Despite a leaf morphotype that is relatively uniform throughout Gondwana in the Permian, the reproductive organs, in particular the ovule-bearing parts of the plant that bore Glossopteris leaves, are both morphologically and anatomically diverse. It should come as no surprise, therefore, that the glossopterids represent a heterogeneous group of Late Paleozoic seed plants, and, like the socalled seed ferns in the Mesozoic, constitute a major challenge in understanding gymnosperm phylogeny. 


\section{Summary}

The glossopterid seed ferns dominated Gondwana during the Permian, which was an important period of transition in seed plant evolution from more archaic Paleozoic forms to those appearing in the Mesozoic. Two types of anatomically preserved ovule-bearing organs of the Glossopteridales occur in a permineralized peat deposit on Skaar Ridge in the central Transantarctic Mountains. Although multiovulate reproductive structures have been found previously in peat from the Bowen Basin of Australia and from Skaar Ridge, this report represents the first anatomical detail of the cupulate type of reproductive organ, as well as the first definitive evidence of ovules found within the cupules. The confirmation of two distinct types of seed-bearing organs in the glossopterids indicates that the group is more diverse than the single leaf morphotype, Glossopteris, would suggest. Anatomically preserved glossopterid reproductive organs are crucial in furthering our knowledge of the relationships within this group, and in understanding their phylogenetic position in relation to the other seed plants.

Acknowledgements. This research was supported by the National Science Foundation (OPP-0229877). We thank current and former researchers in our laboratory and former field party members for their assistance in collecting and processing the permineralized peat. Thank you to Dr. K.B. Pigg for bringing our attention to their 'in press' paper and to two anonymous reviewers for their helpful suggestions on an earlier version of the manuscript.

\section{References}

Anderson, J. M., and H. M. Anderson (1985), Palaeoflora of Southern Africa: Prodromus of South African Megafloras Devonian to Lower Cretaceous, A. A. Balkema, Rotterdam.

Barrett, P. J., and D. J. Elliot (1973), Reconnaissance geologic map of the Buckley Island Quadrangle, Transantarctic Mountains, Antarctica, Antarctic Geol. Map (U.S.G.S.), A-3.

Collinson, J. W., W. R. Hammer, R. A. Askin, and D. H. Elliot (2006), Permian-Triassic boundary in the central Transantarctic Mountains, Antarctica, Geol. Soc. Am. Bull., 118, 747-763.

Cúneo, N. R., J. Isbell, E. L. Taylor, and T. N. Taylor (1993), The Glossopteris flora from Antarctica: Taphonomy and paleoecology, in 12 Congrès Intl. Géol. Carb.-Perm., Comptes Rendus, 2, edited by S. Archangelsky, pp. 13-40.

Doyle, J. A. (2006), Seed ferns and the origin of angiosperms, J. Torrey Bot. Soc., 133, 169-209.

Farabee, M. J., E. L. Taylor, and T. N. Taylor (1991), Late Permian palynomorphs from the Buckley Formation, central Transantarctic Mountains, Antarctica, Rev. Palaeobot. Palynol., 69, 353-368.

Galtier, J. M., and T. L. Phillips (1999), The acetate peel technique, in Fossil Plants and Spores: Modern Techniques, edited by T. P. Jones and N. P. Rowe, pp. 67-70, Geol. Soc. London, UK.

Gould, R., and T. Delevoryas (1977), The biology of Glossopteris: evidence from petrified seed bearing and pollen-bearing organs, Alcheringa, 1, 387-399.

Hermsen, E., Taylor, T. N., Taylor, E. L., and D. W. Stevenson (2007), Cycads from the Triassic of Antarctica: Permineralized cycad leaves, Int. J. Plant Sci., 168(7) (in press)

Hilton, J., and R. M. Bateman (2006), Pteridosperms are the backbone of seed-plant phylogeny, J. Torrey Bot. Soc., 133, 119-168.

Holmes, W. B. K. (1973), On some fructifications of the Glossopteridales from the Upper Permian of N.S.W., Proc. Linn. Soc. New South Wales, 98, 131-141.

Klavins, S. D., E. L. Taylor, M. Krings, and T. N. Taylor (2001), An unusual, structurally preserved ovule from the Permian of Antarctica, Rev. Palaeobot. Palynol., 115, 107-117.
Le Goc, M. J. (1914), Observations on the centripetal and centrifugal xylem in the petioles of cycads, Ann. Bot., 28, 183-193.

McLoughlin, S. (1990a), Late Permian glossopterid fructifications from the Bowen and Sydney Basins, eastern Australia, Géobios, 23, 283297.

McLoughlin, S. (1990b), Some Permian glossopterid fructifications and leaves from the Bowen Basin, Queensland, Australia, Rev. Palaeobot. Palynol., 62, 11-40.

McLoughlin, S. (1993), Glossopterid megafossils in Permian Gondwanic non-marine biostratigraphy, in Gondwana Eight: Assembly, Evolution and Dispersal, edited by R. H. Findlay, R. Unrug, M. R. Banks, and J. J. Veevers, pp. 253-264, A. A. Balkema, Rotterdam, Netherlands.

McManus, H. A., E. L. Taylor, T. N. Taylor, and J. W. Collinson (2002), A petrified Glossopteris flora from Collinson Ridge, central Transantarctic Mountains: Late Permian or Early Triassic?, Rev. Palaeobot. Palynol., 120, 233-246.

Neish, P. G., A. N. Drinnan, and D. J. Cantrill (1993), Structure and ontogeny of Vertebraria from silicified Permian sediments in East Antarctica, Rev. Palaeobot. Palynol., 79, 221-244.

Nishida, H., Pigg, K. B., Kudo, K., and J. F. Rigby (2007), New evidence of reproductive organs of Glossopteris based on permineralized fossils from Queensland, Australia. I. Ovulate organ Homevaleia gen. nov., J. Plant Res., 120, 539-549.

Nixon, K. C., W. L. Crepet, D. Stevenson, and E. M. Friis (1994), A reevaluation of seed plant phylogeny, Ann. Mo. Gard., 81, 484-533.

Pant, D. D. (1977), The plant of Glossopteris, J. Ind. Bot. Soc., 56, 1-23.

Pant, D. D., and R. Pant (1987), Some Glossopteris leaves from Indian Triassic beds, Palaeontographica, 205B, 165-178.

Pant, D. D., and R. S. Singh (1974), On the stem and attachment of Glossopteris and Gangamopteris leaves. Part II - structural features, Palaeontographica, 147B, 42-73.

Pigg, K. B. (1990), Anatomically preserved Glossopteris foliage from the central Transantarctic Mountains, Rev. Palaeobot. Palynol., 66, $105-127$.

Pigg, K. B., and S. L. McLoughlin (1997), Anatomically preserved Glossopteris leaves from the Bowen and Sydney basins, Australia, Rev. Palaeobot. Palynol., 97, 339-359.

Pigg, K. B., and H. Nishida (2006), The significance of silicified plant remains to the understanding of Glossopteris-bearing plants: An historical review, J. Torrey Bot. Soc., 133, 46-61.

Pigg, K. B., and T. N. Taylor (1993), Anatomically preserved Glossopteris stems with attached leaves from the central Transantarctic Mountains, Amer. J. Bot., 80, 500-516.

Retallack, G. J., and D. L. Dilcher (1981), Arguments for a glossopterid ancestry of angiosperms, Paleobiology, 7, 54-67.

Rigby, J. F. (1962), On a collection of plants of Permian age from Barabala, Queensland, Proc. Linn. Soc. New South Wales, 87, 341-351.

Rigby, J. F. (1978), Permian glossopterid and other cycadopsid fructifications from Queensland, Geol. Surv. Queensland Pub., 367, 3-21.

Schopf, J. M. (1976), Morphologic interpretation of fertile structures in glossopterid gymnosperms, Rev. Palaeobot. Palynol., 21, 25-64.

Shah, B. A. (2000), Revision of age of Parsora Formation, Johilla-Son Valley, Rewa Basin, M.P., Indian Minerals, 54, 223-232.

Surange, K. R., and S. Chandra (1973), Denkania indica gen. et sp nov. A glossopteridean fructification from the Lower Gondwana of India, Palaeobotanist, 20, 264-268.

Surange, K. R., and S. Chandra (1975), Morphology of the gymnospermous fructifications of the Glossopteris flora and their relationships, Palaeontographica, 149B, 153-180.

Taylor, E. L., T. N. Taylor, and J. W. Collinson (1989), Depositional setting and paleobotany of Permian and Triassic permineralized peat from the central Transantarctic Mountains, Antarctica, Int. J. Coal Geol., 12, 657-679.

Taylor, E. L., and T. N. Taylor (1992), Reproductive biology of the Permian Glossopteridales and their suggested relationship to flowering plants, Proc. Nat. Acad. Sci., USA, 89, 11495-11497.

Thomas, H. H. (1958), Lidgettonia, a new type of fertile Glossopteris, Bull. Brit. Mus. (Nat. Hist.), Geol., 3, 179-189. 